\title{
CLINICAL EVALUATION OF DENTAL RESTORATIONS IN ADULTS WITH DIFFERENT CARIES RISK PROFILE
}

\author{
FARKLI ÇÜRÜK RİSK PROFİLİNE SAHİP ERİ̧̧KİNLERDE DENTAL \\ RESTORASYONLARIN KLİNİK OLARAK DEĞERLENDİRİLMESİ
}

\section{ABSTRACT}

Aim: The quality of restorations varies depending on many factors such as type of material and caries risk. The objective of this research was to investigate the quality of dental restorations by using the Modified United States Public Health Service criteria (USPHS/Ryge) in adults with different caries risk profile.

Materials and methods: A total of 175 patients and their 642 restorations were divided into $\operatorname{low}(\mathrm{DMFT} \leq 5)$, moderate $(5>$ DMFT $<14)$ or high(DMFT $\geq 14)$ caries risk group. The patients were answered questions about general health, diet and oral hygiene habits. All the restorations were examined clinically according to Modified USPHS criteria. A one way ANOVA was used to compare caries risk groups for the difference in mean age and DMFT scores. The chi-square test was used for determining of differences in caries risk groups across the quality ratings for dental restorations and categories of caries risk factors.

Results: In low caries risk group, anterior restorations were found lower percentage than other caries risk groups. The composite restorations were less frequent and marginal discoloration and surface texture scores presented a higher percentages of unacceptable ratings in high caries risk group $(p<0.05)$. The dental plaque was more as toothbrushing was less frequent in high caries risk group $(\mathrm{p}<0.05)$.

Conclusion: The quality of dental restorations can be determined according to the caries risk profile. To increase the success of restorations in individuals with high caries risk, oral hygiene education will be needed.

Key words: Dental restoration, dental caries, adult, modified USPHS criteria

ÖZ

Amaç: Restorasyonların kalitesi, material tipi ve çürük riski gibi birçok faktöre bağlı olarak değişiklik göstermektedir. Bu çalışmanın amacı, farklı çürük risk profiline sahip erişkinlerde Modifiye Birleşik Devletler Halk Sağlığı Servisi (USPHS/Ryge) kriterlerini kullanarak dental restorasyonların kalitesini araştırmaktır.

Gereç ve Yöntem: Toplam 175 hasta ve 642 restorasyon, düşük (DMFT $\leq 5)$, orta (5>DMFT<14) veya yüksek (DMFT $\geq 14)$ çürük risk grubuna ayrıldı. Hastaların genel sağlık, diyet ve ağız hijyen alışkanlıkları ile ilgili sorulara yanıt vermesi sağlandı. Tüm restorasyonlar modifiye USPHS kriterlerine göre klinik olarak incelendi. Çürük risk grupları arasında yaş ortalaması ve DMFT skorları açısından fark olup olmadığı Tek Yönlü ANOVA testi ile değerlendirildi. Restorasyonların kalitesi ve çürük risk faktörleri kategorilerindeki skorlar açısından çürük risk grupları arasındaki farkı belirlemek için Ki kare testi kullanıldı.

Bulgular: Düşük çürük risk grubunda anterior restorasyon sayısı, diğer risk gruplarına göre daha az oranda saptandı. Yüksek çürük risk grubunda kompozit restorasyonlar daha az sıklıkta bulunurken, marjinal renk değişikliği ve yüzey dokusu kriterleri daha yüksek oranda kabul edilemez skorlarını sergiledi $(p<0.05)$. Yüksek çürük risk grubunda dental plak miktarı daha fazla, diş fırçalama sıklığı daha az olarak belirlendi $(\mathrm{p}<0.05)$.

Sonuç: Dental restorasyonların başarısı çürük risk profiline göre belirlenebilir. Yüksek çürük riskli bireylerin restorasyon başarııını arttırmak için ağız hijyen eğitimi gereklidir.

Anahtar kelimeler: Dental restorasyon, diş çürüğü, erişkin, modifiye USPHS kriterler

*Recep Tayyip Erdoğan Üniversitesi, Diș Hekimliği Fakültesi, Restoratif Diș Tedavisi Anailim Dalı, Rize

Kaynakça Bilgisi Yıldız Telatar G, Bedir F. Farklı Çürük Risk Profiline Sahip Erişkinlerde Dental Restorasyonların Klinik Olarak Değerlendirilmesi. Atatürk Üniv Diş Hek Fak Derg 2020; 30: 88-92.

Citation Information: Yildiz Telatar G, Bedir F. Clinical Evaluation of Dental Restorations in Adults with Different Caries Risk Profile. J Dent Fac Atatürk Uni 2020; 30 88-92 


\section{INTRODUCTION}

Dental caries is a multifactorial disease and is affected by several risk factors. ${ }^{1,2}$ Risk for caries includes genetic, environmental, and lifestyle-related factors such as cariogenic diet, dental plaque, inadequate salivary flow rate, insufficient fluoride exposure, poor oral hygiene and high past caries experience. The approach to primary prevention should be based on eliminating risk factors. Secondary prevention for dental caries should focus on treatment by minimally invasive techniques such as restorative alternatives. $^{3}$

Despite declining caries prevalence in many countries, dental caries are the most common reason of restorative treatment. ${ }^{4,5}$ In dental practice the most preferred restorations are amalgam and composite restorations. Dental amalgam has been selected for restorative material because of some advantages such as less sensitivity to clinical techniques and low cost than the other esthetic materials. Composite restorations are the most preferred treatment option today, not only their aesthetic properties but also ability to adhesion to tooth tissue at the same time. ${ }^{5}$

When evaluating success or failures in dental restorations, researchers have generally made a point of the clinical variables and characteristics related to material type and operators. However, investigation of patient related factors is also important. 4,6

The objective of the this study was to investigate the quality of dental restorations by using the USPHS/Ryge criteria (Modified United States Public Health Service) in adults with different caries risk profile according to DMFT index. Our hypothesis is that the failure of restoration will increase in group of high caries risk.

\section{MATERIALS AND METHODS}

\section{Ethics}

The study protocol was confirmed by the Ethics Committee of Recep Tayyip Erdogan University Faculty of Medicine (date: 16.03.2018; no:2018/57) and approval form was obtained from all individuals at the beginning of the study.

\section{Subjects}

The participants were among the patients that applied the Faculty of Dentistry in Rize. A total of 175 adults were involved in the study and participants were divided into low (DMFT $\leq 5)$, moderate $(5>$ DMFT $<14)$ or high $(\mathrm{DMFT} \geq 14)$ caries risk group.
The exclusion criteria were dental and systemic fluorosis, genetic diseases and orthodontic appliances. The patients were answered questions about general and dental health, dietary intake between meals, oral hygiene and frequency of tooth brushing and dental visit.

\section{Clinical examination}

All individuals received dental examination performed by two dentists. The kappa value was determined to be 0.8 . The dental and radiographic evaluation was applied using a sterile dental mirror and explorer under a dental chair's light. After the visual inspection and digital panoramic radiographs (Orthopantomograph ${ }^{\circledR} \quad$ OP300 Panoramic, Instrumentarium Dental, Tuusula, Finland) caries index of all patients was scored.

The teeth were examined and recorded as decayed, missing or filled (DMFT). ${ }^{7,8}$ The plaque amount were estimated using Silness and Löe's scale. The plaque was evaluated through collection from the mesial and distal, vestibular, palatinal or lingual surfaces.

The 642 dental restorations were examined clinically in keeping with Modified USPHS/Ryge criteria. The following criteria: (1) retantion, (2) marginal integrity, (3) marjinal discoloration, (4) anatomic form, (5) surface texture, (6) recurrent caries were evaluated in terms of determining quality of dental restorations. (Table 1 ). The criteria of $A$ or $B$ was detected to be clinically 'acceptable', and C or D was evaluated clinically 'unacceptable'. The type of material and tooth were also scored in the study.

Table 1. The modified USPHS/Ryge criteria

\begin{tabular}{ll}
\hline $\begin{array}{l}\text { Category and } \\
\text { rating }\end{array}$ & Criteria* \\
\hline Retention & A: Retained \\
Marginal & B: Missing \\
integrity & B: No visible gap \\
& C: There is visible gap \\
& exposed \\
& D: The restoration is mobile, partially or totally \\
Marginal & fractured or lost \\
discoloration & A: No discoloration \\
& B: Discoloration is present but has not penetrated \\
Anatomic & D: Deep staining (not removable, generalized) \\
form & A. The restoration is continuous with existing \\
& anatomic form \\
Surface & B. Generalized wear but clinically acceptable \\
texture & C. Sufficient material is lost to expose dentin \\
& B: Smooth \\
Recurrent & C: Low-surface roughness \\
caries & A: No evidence of caries \\
\hline
\end{tabular}

${ }^{*} A=$ Alfa; $B=$ Bravo; $C=$ Charlie, $D=$ Delta 


\section{Statistical analysis}

All analyses were realized using SPSS 20.0 Statistical Package Program (IBM SPSS Statistics for Windows, Version 20.0, Chicago, IL, USA). The quality ratings for the 642 dental restorations were estimated for providing the frequency distribution. A one way ANOVA is used to compare caries risk groups for the difference in scores of DMFT and mean age. The chisquare test was used for determining of diversity in all caries risk groups across the categories of caries risk factors and quality ratings for dental restorations.

\section{RESULTS}

The distribution of participants and restorations according to the DMFT score is shown in Table 2. A total of 175 individuals were examined and the distributions of dental restorations in low, moderate and high caries risk group were 85 (13.2\%), 405 (63.1\%) and $152(23.7 \%)$ respectively. No significant gender differences were observed among the caries risk categories $(p=0.688)$. Table 3 displays the distribution of restorations according to (USPHS)/Ryge criteria in caries risk groups with chi square test. There were significant differences among caries risk groups in terms of restorative material and tooth type. In low caries risk group anterior restorations were found significantly less frequent in contrast high caries risk group. The dental restorations in low caries risk profile exhibited a lower percentage of unacceptable scores than high caries risk profile, with regard to, marginal discoloration and surface texture $(p<0.05)$.

Table 2. Characteristics of the study sample

\begin{tabular}{|c|c|c|c|}
\hline Characteristics & $\begin{array}{l}\text { Low caries } \\
\text { risk group } \\
\text { (DMFT } \leq 5 \text { ) }\end{array}$ & $\begin{array}{l}\text { Moderate } \\
\text { caries risk } \\
\text { group } \\
(5<\text { DMFT }>14)\end{array}$ & $\begin{array}{l}\text { High caries } \\
\text { risk group } \\
\text { (DMFT } \geq 14)\end{array}$ \\
\hline Participants(n) & 42 & 107 & 26 \\
\hline Restoration (n) & $85(13.2)$ & $405(63.1)$ & $152(23.7)$ \\
\hline Female & $28(66.7 \%)$ & $75(70.1 \%)$ & $16(61.5 \%)$ \\
\hline \multirow[t]{2}{*}{ Male } & $14(33.3 \%)$ & $32(29.9 \%)$ & $10(38.5 \%)$ \\
\hline & \multicolumn{2}{|c|}{ p value $=0.688$} & \\
\hline \multirow[t]{2}{*}{$\begin{array}{l}\text { Age } \\
(\text { mean } \pm S D)\end{array}$} & $34.5(13.32)$ & $32.1(12.32)$ & $29.3(9.7)$ \\
\hline & \multicolumn{2}{|c|}{$\mathrm{p}$ value $=0.226$} & \\
\hline $\begin{array}{l}\text { DMFT } \\
(\operatorname{mean} \pm S D)\end{array}$ & $4.02(1.123)$ & $8.64(2.270)$ & $15.92(2.255)$ \\
\hline $\begin{array}{l}(\text { mean } \pm S D) \\
\text { DT }\end{array}$ & $\begin{array}{l}0.72 \\
(0.670)\end{array}$ & $2.14(1.495)$ & $3.88(1.732)$ \\
\hline MT & $0.65(0.780)$ & $1.67(1.433)$ & $3.91(2.121)$ \\
\hline FT & $2.62(1.234)$ & $4.93(2.265)$ & $8.38(3.747)$ \\
\hline \multicolumn{4}{|c|}{$\mathrm{p}$ value $=\mathbf{0 . 0 0 0}$} \\
\hline
\end{tabular}

Table 4 shows the distribution of adults by demographic factors and behavioural caries risk predictors. According to low caries risk profile, the toothbrushing frequency was less and dental plaque amount was more in high caries risk group $(p<0.05)$. There was no significant differences in the distribution of locality, sweet intake between meals and dental visit between caries risk groups.

Table 3. The differences in caries risk profiles across the modified USPHS criteria and categories of tooth type and material

\begin{tabular}{|c|c|c|c|}
\hline Categories/rating & $\begin{array}{c}\text { Low caries } \\
\text { risk group } \\
(\mathrm{DMFT} \leq 5), \\
\mathrm{n}(\%)\end{array}$ & $\begin{array}{c}\text { Moderate } \\
\text { caries risk } \\
\text { group } \\
(5<\text { DMFT >14), } \\
n(\%)\end{array}$ & $\begin{array}{c}\text { High caries } \\
\text { risk group } \\
\text { (DMFT } \geq 14), \\
n(\%)\end{array}$ \\
\hline \multicolumn{4}{|l|}{ Tooth type } \\
\hline anterior & $8(9.4)$ & $45(11.1)$ & $38(25.0)$ \\
\hline premolar & $23(27.1)$ & $117(28.9)$ & $46(30.3)$ \\
\hline molar & $54(63.5)$ & $\begin{array}{l}243(60.0) \\
p=0.000\end{array}$ & $68(44.7)$ \\
\hline \multicolumn{4}{|l|}{ Material } \\
\hline Composite & $69(81.2)$ & $237(58.5)$ & $100(65.8)$ \\
\hline Amalgam & $16(18.8)$ & $\begin{array}{l}168(41.5) \\
\mathbf{p}=\mathbf{0 . 0 0 0}\end{array}$ & $52(34.2)$ \\
\hline \multicolumn{4}{|l|}{ Retention } \\
\hline Restoration present & $83(97.6)$ & $384(95.0)$ & $139(91.4)$ \\
\hline Restoration absent & $2(2.4)$ & $\begin{array}{l}20(5.0) \\
p=0.100\end{array}$ & $13(8.6)$ \\
\hline \multicolumn{4}{|l|}{$\begin{array}{l}\text { Marginal } \\
\text { integrity }\end{array}$} \\
\hline A & $61(71.8)$ & $243(60.0)$ & $100(65.8)$ \\
\hline B & $20(23.5)$ & $138(34.1)$ & $46(30.3)$ \\
\hline $\mathrm{C}$ & $1(1.2)$ & $9(2.2)$ & $1(0.7)$ \\
\hline $\mathrm{D}$ & $3(3.5)$ & $\begin{array}{l}15(3.7) \\
p=0.401\end{array}$ & $5(3.3)$ \\
\hline \multicolumn{4}{|l|}{$\begin{array}{c}\text { Marginal } \\
\text { discoloration }\end{array}$} \\
\hline$A$ & $61(71.8)$ & $265(65.8)$ & $44(28.9)$ \\
\hline B & $20(23.5)$ & $112(27.8)$ & $48(31.6)$ \\
\hline $\mathrm{C}$ & $2(2.4)$ & $11(2.7)$ & $22(14.5)$ \\
\hline$D$ & $2(2.4)$ & $\begin{array}{c}15(3.7) \\
\mathbf{p}=\mathbf{0 . 0 0 0}\end{array}$ & $38(25.0)$ \\
\hline \multicolumn{4}{|l|}{ Anatomic form } \\
\hline $\mathrm{A}$ & $65(76.5)$ & $287(71.2)$ & $98(64.5)$ \\
\hline $\mathrm{B}$ & $15(17.6)$ & $94(23.3)$ & $41(27.0)$ \\
\hline $\mathrm{C}$ & $5(5.9)$ & $\begin{array}{l}22(5.5) \\
p=0.289\end{array}$ & $13(8.5)$ \\
\hline \multicolumn{4}{|l|}{ Surface texture } \\
\hline $\mathrm{A}$ & $57(67.1)$ & $233(57.8)$ & $65(43.0)$ \\
\hline B & $26(30.6)$ & $150(37.2)$ & $76(50.3)$ \\
\hline $\mathrm{C}$ & $2(2.4)$ & $\begin{array}{c}20(5.0) \\
\mathbf{p}=\mathbf{0 . 0 0 4}\end{array}$ & $10(6.6)$ \\
\hline \multicolumn{4}{|l|}{ Recurrent caries } \\
\hline $\mathrm{A}$ & $72(84.7)$ & 355 (87.9) & $130(85.5)$ \\
\hline B & $13(15.3)$ & $\begin{array}{l}49(12.1) \\
p=0.623\end{array}$ & $22(14.5)$ \\
\hline
\end{tabular}


Table 4. Distribution of adults by demographic factors and behavioural caries risk predictors.

\begin{tabular}{|c|c|c|c|}
\hline Variable/category & $\begin{array}{l}\text { Low caries } \\
\text { risk group } \\
(\mathrm{DMFT} \leq 5) \text {, } \\
\mathrm{n}(\%)\end{array}$ & $\begin{array}{l}\text { Moderate caries } \\
\text { risk group, } \\
(5<\text { DMFT>14), } \\
\text { n (\%) }\end{array}$ & $\begin{array}{l}\text { High caries } \\
\text { risk group } \\
(\mathrm{DMFT} \geq 14) \text {, } \\
\text { n }(\%)\end{array}$ \\
\hline \multicolumn{4}{|c|}{ 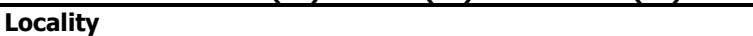 } \\
\hline Urban & $27(64.3)$ & $66(61.7)$ & $20(76.9)$ \\
\hline Rural & $15(35.7)$ & $\begin{array}{l}41(38.3) \\
p=0.589\end{array}$ & $6(23.1)$ \\
\hline \multicolumn{4}{|l|}{ Toothbrushing } \\
\hline $\begin{array}{l}\text { >twice a day } \\
\text { Twice a day }\end{array}$ & $\begin{array}{l}8(19.0) \\
17(40.5)\end{array}$ & $\begin{array}{l}10(9.3) \\
48(44.9)\end{array}$ & $\begin{array}{l}1(3.8) \\
7(26.9)\end{array}$ \\
\hline Once a day & $11(26.2)$ & $39(36.4)$ & $9(34.6)$ \\
\hline <once a day & $6(14.3)$ & $\begin{array}{l}10(9.3) \\
\mathbf{p}=\mathbf{0 . 0 1 4}\end{array}$ & $9(34.6)$ \\
\hline \multicolumn{4}{|l|}{ Dental plaque } \\
\hline $\mathrm{PI}<0.4$ & $17 \quad(40.5)$ & $33(30.8)$ & $6(23.1)$ \\
\hline$P I=0.4-1.0$ & $9(21.4)$ & $36(33.6)$ & $5(19.2)$ \\
\hline$P I=1.1-2.0$ & $11(26.2)$ & $29(27.1)$ & $5(19.2)$ \\
\hline $\mathrm{PI}>2$ & $5(11.9)$ & $\begin{array}{l}9(8.4) \\
\mathbf{p}=\mathbf{0 . 0 0 5}\end{array}$ & $10(38.5)$ \\
\hline \multicolumn{4}{|l|}{$\begin{array}{l}\text { Sweet intake } \\
\text { between meals }\end{array}$} \\
\hline Less than $1 /$ day & $18(42.9)$ & $48(44.9)$ & $14(53.8)$ \\
\hline 1 or $2 /$ day & $21(50.0)$ & $46(43.0)$ & $7(26.9)$ \\
\hline 3 or $4 /$ day & $2(4.8)$ & $9(8.4)$ & $4(15.4)$ \\
\hline 5 or more/day & $1(2.4)$ & $\begin{array}{l}4(3.7) \\
p=0.567\end{array}$ & $1(3.8)$ \\
\hline \multicolumn{4}{|l|}{ Dental visit } \\
\hline Every 6 months & $2(4.8)$ & $17(15.9)$ & $2(7.7)$ \\
\hline Per a year & $3(7.1)$ & $10(9.3)$ & $6(23.1)$ \\
\hline Not usually & $37(88.1)$ & $\begin{array}{l}80(74.8) \\
p=0.065\end{array}$ & $18(69.2)$ \\
\hline
\end{tabular}

*p values based on $x 2$ test, $p<0.05$

\section{DISCUSSION}

Studies have shown that the quality of restorations can be increased by eliminating long-term factors of caries risk. In addition, caries risk assessment can result in less costly dental treatment. ${ }^{9,10}$ There is no studies made in Turkey about the quality of restorations, but there is adequate argument of caries risk in Turkey. Therefore, in our study the quality of dental restoration in adults with different caries risk profiles were examined.

It was reported that the results obtained by supporting panoramic films with bitewing radiographs in the detection of interproximal caries, are very close to the results obtained with full mouth radiographic series. ${ }^{11}$ In this study, digital panoramic radiographs were used for the diagnosis of interproximal caries, and bitewing radiographs were preferred for the presence of superpositions.

We hypothesized that the failure of restoration would increase in high caries risk group. For that reason the participants were divided into three groups with regard to the DMFT index. Epidemiological studies have shown that DMFT index is a strong caries risk indicator for determining caries risk profile. ${ }^{12,13}$

According to present study composite restorations were found significantly more prevalent in low caries risk profile than moderate and high caries risk profile. This result is similar to the result of Correa et al. who explained composite restorations were less preferred than amalgam because of expensive price. So, in our study individuals with higher caries risk could prefer amalgam restoration rather than composite. ${ }^{5}$

Luen et al. examined for ten years incidance of dental caries in adults and they detected the molar teeth were most susceptible to caries and caries incidence of anterior teeth was lower. ${ }^{14,15}$ Similarly, we found anterior restorations were found significantly less frequent in low caries risk group than other risk groups.

According to the our research, the surface texture and marginal discoloration exhibited a high percentage of unacceptable restorations in adults with high caries risk profile. This is probably because patients had significantly more dental plaque in high caries risk group.

In present study we found no significant association between recurrent caries and caries risk profiles. This is why there were no significant association between retention, marginal integrity, anatomic form and caries risk groups. This finding is similar to another study which researcher reported that the most common area of recurrent caries was the gingival wall in class II restorations. They speculate if marginal form is disturbed enough to plaque deposit, the recurrent caries can become to start easier in this region. ${ }^{9}$ Although in other studies oral hygiene has been found as a determinant of recurrent caries, this did not occur in the current study but we found higher frequency of the toothbrushing in the low caries risk profile than other profiles. ${ }^{16}$

Researchers suggested that frequency of the sugar intake is important but self reporting of diet has low predictability for caries risk profile. ${ }^{17,18}$ Similarly, we found no significant association between sweet intake between meals and caries risk groups.

\section{CONCLUSION}

In conclusion, anterior composite restorations were less frequent and the quality of marginal discoloration and surface texture was unacceptable in 
high caries risk group. The success of the dental restorations can be extended by taking preventive measures with caries risk assessment. Regular oral hygiene habits of the patients may also enhance durability of dental restorations. Limitation of health care cost should be targeted with studies that investigate the true causes of the failure of restorations.

NOT: Çalışmada herhangi bir yazar, kurum ya da kuruluş ile çıkar çatışması içerisinde bulunmamaktadır. Makale daha önce hiçbir yerde yayınlanmamış ve yayınlanmak üzere işlem görmemektedir

\section{REFERENCES}

1. Basavaraj P, Khuller N, Khuller RI, Sharma N. Caries risk assessment and control. J Oral Health Comm Dent 2011; 5:58-63.

2. Ruiz Miravet A, Montiel Company JM, Almerich Silla JM. Evaluation of caries risk in a young adult population. Med Oral Patol Oral Cir Bucal 2007; 12:412-8.

3. Selwitz RH, Ismail AI, Pitts NB. Dental caries. Lancet 2007; 369:51-9.

4. Sonbul H, Al-Otaibi M, Birkhed D. Risk profile of adults with several dental restorations using the Cariogram model. Acta Odontol Scand 2008; 66:351-7.

5. Correa MB, Peres MA, Peres KG, Horta BL, Barros $A D$, Demarco FF. Amalgam or composite resin? Factors influencing the choice of restorative material. J Dent 2012; 40:703-10.

6. Correa MB, Peres MA, Peres KG, Horta BL, Barros AJ, Demarco FF. Do socioeconomic determinants affect the quality of posterior dental restorations? A multilevel approach. J Dent 2013; 41:960-7.

7. World Health Organization, Oral Health Surveys: Basic Methods, 4th ed. Geneva:1997.

8. Çongara Kıvrak $T$ ve Mokhtari Tavana A. Diş Hekimliği Fakültesi Öğrencilerinde Beslenme Alışkanlığı, Ağız Diş Sağlığı Tutum ve Davranışları ve DMFT Indeksinin Değerlendirilmesi. A. Ü. Diş Hek. Fak. Derg 2017; 44:1-7.

9. Mjör IA. Clinical diagnosis of recurrent caries. J Am Dent Assoc 2005; 136:1426-33.

10. Miyamoto T, Morgano SM, Kumagai T, Jones JA, Nunn ME. Treatment history of teeth in relation to the longevity of the teeth and their restorations: outcomes of teeth treated and maintained for 15 years. J Prosthet Dent 2007; 97:150-6.
11. Akkaya N, Kansu O, Kansu H, Cagirankaya LB, Arslan U. Comparing the accuracy of panoramic and intraoral radiography in the diagnosis of proximal caries. Dentomaxillofac Radiol 2006; 35:170-4.

12. Fontana M, Zero DT. Assessing patients' caries risk. J Am Dent Assoc 2006; 137:1231-9.

13. Zemaitiene $M$, Grigalauskiene $R$, Andruskeviciene V, Matulaitiene ZK, Zubiene J, Narbutaite J, Slabsinskiene E. Dental caries risk indicators in early childhood and their association with caries polarization in adolescence: a cross-sectional study. BMC Oral Health. 2016; 17:2.

14. Demirci M, Tuncer S, Yuceokur AA.Prevalence of caries on individual tooth surfaces and its distribution by age and gender in university clinic patients. Eur J Dent. 2010; 4:270-9.

15. Luan W, Baelum V, Fejerskov O, Chen X. Ten-year incidence of dental caries in adult and elderly Chinese. Caries Res. 2000; 34:205-13.

16. Maldupa I., Brinkmane,A. Mihailova A. and Rendeniece I. The impact of dental restorations' quality on caries risk. SHS Web of Conferences 2, EDP Sciences 2012; 2:1-10.

17. Reich E, Lussi A, Newbrun E. Caries risk assessment. Int Dent J 1999; 49: 15-26.

18. van Loveren C Sugar Restriction for Caries Prevention: Amount and Frequency. Which Is More Important? Caries Res. 2018; 53:168-75.

\author{
Yazışma Adresi \\ Dr. Öğr. Üyesi Gül YILDIZ TELATAR \\ Recep Tayyip Erdoğan Üniversitesi \\ Diş Hekimliği Fakültesi, \\ Restoratif Diş Tedavisi Anabilim Dalı \\ 53000 Rize \\ Telefon: 04642220000 \\ Fax: 04642220002 \\ E-mail: gulyildiz@gmail.com
}

